\title{
An examination of the relationship between CSR disclosure and financial performance: The case of Polish banks
}

\author{
Łukasz Matuszak $^{\mathrm{a} 1}$ and Ewa Różańska ${ }^{\mathrm{a}}$

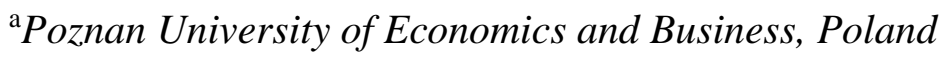

\begin{abstract}
The purpose of this study is twofold. First, this study investigates the trends of corporate social responsibility (CSR) reporting and financial performance (FP) in commercial banks in Poland. Second, this study examines the impact of the CSR disclosure of the banks on their financial performance (ROA, ROE, NIM). Sample consists of 18 banks. The data from annual reports for the period of 8 years (2008 - 2015) were both hand collected and obtained from Notoria Servis Database. A content analysis is used to measure the level of CSR disclosures and a panel data analysis is employed to examine the CSR-FP relationship. Software: GRETL. Two key findings: (1) Positive relationship between banks' CSR disclosures and their profitability measured by ROA and ROE. However, the relationship between banks' CSR disclosures and NIM is negative. Statistical analysis did not report any significant effect of CSR activities on ROA, ROE and NIM ratios. (2) Banks' CSR activities are not dominant predictor of their profitability as compared with control variables. To our best knowledge this research is the first quantitative analysis regarding banking sector in Poland. Further, this study was conducted in emerging market with different socio-economic context and regulations compared to developed market. The findings contribute to and increase the understanding of the relationship between CSR disclosures and FP. Finally, this study has important implications for policy makers, managers, investors, and others.
\end{abstract}

1 Corresponding authors: Department of Accounting, Poznan University of Economics and Business; Al. Niepodległości 10, 61-875Poznań; tel. (+48) 6185438 38; email addresses: lukasz.matuszak@ue.poznan.pl,ewa.rozanska@ue.poznan.pl 
Key words: corporate social responsibility, financial performance, polish banks.

JEL Codes: C33, G21, G32, M14, M41

\section{Introduction}

The beginning of the 21 st century brought several financial scandals due to managerial opportunism and large scale of accounting fraud, reducing stakeholders' confidence in business enterprises. The accounting scandal at Enron, the Wall Street's crisis occurred in 2008 and the Madoff scandal raised comments referred as "a decay in business morality" (Chih et al., 2010). To a large extent, the social consequences of these crisis created reputational issue for organizations, limiting their competitiveness and profitability.

Above mentioned criticism could possibly explain why business representatives, general public leaders, governments, investors and other stakeholders become proponents of the postulate according to which the company cannot pursue a strategy to maximize the financial result at the expense of fulfilling its obligations towards its employees, the environment and society as a whole. In response to this claim, companies begin implementing social responsibility activities and other strategies that allow them to improve their reputation and restore stakeholders' confidence (Servaes \& Tamayo, 2013).

In the light of the above corporate social responsibility (CSR) has gained recognition and acceptance among stakeholders of the company and company itself. CSR is the subject of standardization within the guidelines of various kinds (e.g. GRI, ISO, Integrated reporting) both in voluntary or mandatory variant. Moreover, in many countries CSR indices are developed, emerging companies operating in sustainable and responsible manner, such as Dow Jones Sustainability Index (DJSI), the Financial Times Stock Exchange's FTSE4Good, the Fortune 500, Johannesburg Securities Exchange (JSE) index and Warsaw Stock Exchange's RESPECT index. These indices assess companies based on various criteria such as human rights, protection of environment, working conditions, labour standards, supply chain management.

Despite the fact that Corporate Social Responsibility (CSR) is currently widely discussed in theory and practice there is no general agreement about its definition. Definitions presented in the literature stress different aspects of CSR concept, such as: sustainability, sustainable development, corporate responsibility, triple-bottom line, corporate ethics, corporate citizenship, social enterprise, and corporate governance (Bassen et al., 2006). Each of definitions in varied way specify the scope of the concept. Moreover, as yet, no definition has won such an advantage over 
others, that it was reasonable to consider it as absolutely dominant. Inaccuracies in defining CSR can be considered as a manifestation of the unsatisfactory state of the theoretical development of the concept of CSR. Although the occurrence in the literature various definitions and terms of CSR could also be regarded as an expression of the evolution and expansion of the scope in research on CSR, which today has already some achievements.

A corporation is generally encouraged to adopt CSR because of its perceived benefits. In long-term perspective CSR should improve companies' competitiveness and reputation and positively affect relationship between CSR activities of a company and its financial performance (FP). Although vast research has been undertaken in CSR area, the related studies have focused on the existence of the relationship between CSR and FP (Ambec \& Lanoie, 2008; Dixon-Fowler et al., 2013; Orlitzky et al., 2003; Sharma \& Starik 2002). However, researchers analysing relationship between CSR and FP formulate mixed results. Much of research and literature on CSR has been focused on developed markets, where organizations and institutions are more efficient and effective while research in emerging markets on the subject is limited (Dumitrescu \& Simionescu, 2015; Arli \& Lasmono, 2010). Therefore, there is a need for critical CSR research agenda focusing on developing economies, especially in the Central and Eastern Europe (CEE) countries that do not have a long CSR tradition and practice. According to Albu et al. (2016) CSR has evolved differently depending on the economic, legal and social condition of each CEE country. Thus, various empirical CSR research is needed to understand the differences in CSR applications and effects and to explain the existing differences in certain countries. These research should lead to more relevant CSR-related concepts, frameworks or models that are more applicable to CEE countries.

This study was conducted in Poland that is perceived as a very important emerging market in CEE. In Poland CSR concept is relatively new. After many years of communist system in Poland that can be characterized by dispossession of private capital, CSR issues were under State's responsibility and were not subject of scientific discussion. After 1989 the communism fell and Polish market started to change in the direction of free market economy, following the model of the developed markets (Waniak-Michalak et al., 2016).

Taking this into account Poland is under-researched country comparing with other European countries. Majority of studies on CSR in Poland is descriptive and focuses mainly on range of CSR disclosures leaving other important aspects completely unexplored. For example, to our best knowledge no existing study has explored empirically the impact of CSR practices on companies' financial performance (measured by return on assets [ROA] and return on equity [ROE] and net interest margin [NIM]). In authors opinion, this is an important issue worth investigating, taking into account the general argument that CSR benefits not only stakeholders but also the companies themselves. 
This research was done in banking sector. Banks were selected for the study because of several reasons. First, banking industry is profit-orientated and managers of banks have a responsibility to maximize profits. Second, banks play an important role in social and economic development of a country. Molyneux et al. (2014) suggest that under some conditions, private banks should be treated as public utilities. Third, banks have been considered as public trust institutions for a long time, which imposes special obligations associated with social responsibility on them. Szpringer (2009) states, that values such as protection of the environment, safety working conditions, fairness, regional and local development in the context of global competiveness and retail banking have an increasing impact on the banking market. Fourth, although the number of studies concerning banks, both in the context of undertaking CSR-related activities as well as reporting about them, has increased in recent years, they are still insufficient. Previous studies on CSR reporting in banks employed rather descriptive methods. This research analyses the issue in more exhaustive way. Fifth, in many prior studies on the link between CSR and FP, banks were excluded from research sample as they have little direct environmental impact (Siregar \& Bachtiar, 2010). This study contributes to the existing literature by extending previous studies of CSR reporting on banking sector.

The purpose of this study is twofold. First, this study investigates the trend of corporate social responsibility (CSR) reporting and financial performance (FP) in commercial banks in Poland. Second, this study examines the impact of the CSR disclosures of the banks on their financial performance (ROA, ROE, NIM).

The remainder of this paper is organized as follows. The next section reviews the existing literature and discusses the theoretical background of the study. Section 3 presents the research methodology: describes data collection process, illustrates the construction of our CSR index and others variables, and discusses the econometric models used in this study. Section 4 presents the empirical results and interpretation. Finally, section 6 summarizes the results presented and interpreted, leading to a discussion of their theoretical and practical implications. The article concludes with a recommendation regarding future research agendas.

\section{Literature review and hypotheses development}

A number of theoretical perspectives have been examined in the literature on the relation between CSR disclosure and firm's financial performance. There is generally expected to be a positive relationship between CSR disclosure and financial performance according to socio-political theories - stakeholder theory (Freeman, 1984) and legitimacy theory (Suchman, 1995). Both these theories employ a stakeholder perspective. 
According to Freeman (1984) a stakeholder is a "group or individual who can affect or is affected by the achievement of the organization's objectives". From these perspective, stakeholder theory recognizes the important impact of stakeholders on enterprise sustainability and success. Therefore, enterprises must manage stakeholder relationships by meeting the needs and expectations of diverse stakeholder groups - including environmental, employee, and societal groups (Freeman \& Evan, 1990) - to be successful. Stakeholders express specific expectations with regard to an enterprise CSR activity such as effective use of natural resources, limitation of waste of resources, prevention of pollution, providing workforce diversity, employing the disabled, elimination of discrimination, etc. (Adebayo, 2000). So, environmental and social disclosures are made because they are demanded by stakeholders to satisfy their needs and expectations (Gray et al., 1995a).

Legitimacy theory (Suchman, 1995), associated with the concept of "social contract" (Patten, 1991, 1992), recognizes the importance of stakeholder expectations and has been widely used in accounting research (e.g., Branco \& Rodrigues, 2006) as a mechanism for understanding voluntary CSR activities and disclosures. According to Suchman (1995) legitimacy is "a generalized perception or assumption that the actions of an entity are desirable, proper or appropriate within some socially constructed system of norms, values, beliefs and definitions". It is a process "by which an organisation seeks" approval of the society (Kaplan \& Ruland, 1991) through ensuring "congruence between the social values associated with or implied by their activities and the norms of acceptable behaviour in the larger social system in which they are a part. In so far as these two value systems are congruent we can speak of organizational legitimacy" (Matthews, 1993). In a strong form of legitimacy, enterprises try to meet social expectations and behave in a way that society demands from them (Patten, 2000) through real socially responsible activities. While in a week form of legitimacy information is provided through CSR disclosure by management (Cho \& Patten, 2007; Freedman \& Patten, 2004; Patten, 2002) even if this information does not reflect actual CSR performance.

The stakeholder theory and the legitimacy theory have a lot in common. According to Deegan and Blomquist (2006) stakeholder and legitimacy theories state that companies use social and environmental disclosure to enhance their status, provide information to stakeholders regarding their activities and discharge the social contract between companies and social and environmental organizations. However, as Deegan (2002) points out, the legitimacy theory, refers in its deliberations to society understood as a whole and to general social expectations. On the contrary, the stakeholder theory assumes explicit existence of various groups, which have different expectations and different power or capacity to put pressure on the companies to communicate social and environmental information. 
Busch and Hoffmann (2011) emphasize that stakeholder theory, referred to as good management theory, is about doing good to those that the firm interacts with in order to create the enabling environment for the business firm to gain competitive advantage and grow. This approach assumes that being a good corporate citizen can also make a firm more profitable.

Haniffa and Cooke (2005) suggest also that enterprises that operate under some system of norms, values, beliefs and definitions prevailing among their stakeholders, can reduce the legitimacy gap by communicating more social and environmental information and thus improve their profitability.

Meeting corporate social responsibilities created by stakeholders' expectations builds trust and legitimacy which improves stakeholder relationships and leads to many other benefits. CSR disclosures may affect corporate financial performance through several crucial aspects: increased employees' motivation and productivity, increased products' acceptance among customers, increased acceptance among investors who support social or environmental values. Overall, the expected benefits of CSR disclosures may largely exceed their costs implying higher corporate financial performance (Khlif et al., 2015).

As a result of the financial performance, enterprises can also realize capital market benefits from superior CSR performance, which in turn lead to higher values for these enterprises. The capital market benefits include especially a lower cost of equity capital (Dhaliwal et al., 2011), and a lower cost of debt (Husted, 2005).

Although, the empirical studies which consider corporate performance as a consequence of social and environmental disclosure started over 6 decades ago, the literature presents inconclusive findings.

In fact, a number of narrative and meta-analytic reviews in the recent literature (Ambec \& Lanoie, 2008; Dixon-Fowler et al., 2013; Orlitzky et al., 2003; Sharma $\&$ Starik, 2002) suggest a positive relationship between corporate social performance and corporate financial performance.

But in many empirical studies the fundamental contextual condition of stakeholder theory is not recognized. Stakeholders' goals, objectives and aspirations tend to differ across the contexts of industrial and national boundaries (Baird et al., 2012). Thus, combining the CSR ratings of different industries and different countries may lead to inconsistencies, even though such a strategy yields more of positive CSR and financial performance relation. A better approach is therefore to conduct the study in the context of each industry and each country (Baird et al., 2012; Soana, 2011).

Many sectors of the economy are still under-researched. As for the banking sector, the effect of corporate social responsibility on financial performance has not been 
examined extensively, and the few existing studies offer conflicting evidence. For example, Chih et al. (2010) empirically investigate a total of 520 financial firms in 34 countries between the years 2003 and 2005, and conclude that CSR and financial performance are not related. In contrast, Wu \& Shen (2013) analyse 162 banks in 22 countries over 2003-2009, and report that CSR is positively associated with financial performance in terms of return on assets, return on equity, net interest income, and noninterest income. They also find that CSR negatively associates with nonperforming loans. Differences in the results could be related to measurement issues, differences in sample as well as sample period. To obtain the unbiased and fullblown CSR effect Shen et al. (2016) apply three novel estimation methods, namely, conventional propensity score matching method, nearestneighbor variance biascorrected matching method (nn-VBC) and Heckman's two-step method in switching regression. They collect data about CSR and non-CSR banks from 18 countries. Regardless of the methods used, CSR banks significantly outperform non-CSR banks in terms of return on assets and return on equity.

With respect to banking sector, several studies have investigated the relation between corporate social responsibility and financial performance in different countries (Cornett et al., 2016 in U.S., Adeyanju, 2012 in Nigeria, Ofiri et al., 2014 in Ghana, Soana, 2011 in Italy, Tafti et al., 2012 in Iran, Taskin, 2015 in Turkey and Weshah et al., 2012 in Jordan). A greater number of these studies show a positive correlation between CSR and firms' financial performance (Cornett et al., 2016 in U.S., Adeyanju, 2012; Ofiri et al., 2014; Tafti et al., 2012; Weshah et al., 2012). Mixed relationships were found in Taskin (2015), while no relationship between CSR and financial performance was presented in Soana (2011).

The fact that none of these studies was focused specifically on the Polish banking sector is indicative of a gap that needs to be filled to enrich the literature. This may be done by empirical research that bring evidence of the measurable payoff of CSR activity to Polish banks.

To measure bank financial performance researchers, use two kinds of measurement approach which is accounting-based financial performance (e.g. Soana, 2011; Weshah et al., 2012; Wu \& Shen, 2013; Ofori et al., 2014; Taskin, 2015, Cornett et al., 2016 Shen et al. 2016) and market-based financial performance (e.g. Soana, 2011; Tafti et al., 2012).

In our analysis, we consider financial performance from the accounting perspective and following the previous studies we use three measures of bank profitability, that are generally investigated: average Return on Assets (ROA), average Return on Equity (ROE) and Net Interest Margin (NIM). 
Based on the above theoretical justifications and empirical literature, the following hypotheses are tested:

$\mathrm{H}_{1}$ : There is a positive relationship between Polish banks' CSR disclosure and their financial performance measured by ROA.

$\mathrm{H}_{2}$ : There is a positive relationship between Polish banks' CSR disclosure and their financial performance measured by ROE.

$\mathrm{H}_{3}$ : There is a positive relationship between Polish banks' CSR disclosure and their financial performance measured by NIM.

Even though in the previous studies correlation have been found, the strength of CSR disclosure contribution to banks' profitability has not been discussed widely. Thus, the next hypotheses are tested:

$\mathrm{H}_{4}$ : Polish banks' CSR disclosure significantly contribute to their profitability measured by ROA.

$\mathrm{H}_{5}$ : Polish banks' CSR disclosure significantly contribute to their profitability measured by ROE.

$\mathrm{H}_{6}$ : Polish banks' CSR disclosure significantly contribute to their profitability measured by NIM.

\section{Research methodology}

\subsection{Sample and research data}

Empirical studies have been conducted on the population of all commercial banks, which have operated in the years 2008 - 2015 in Poland and which have made available their financial statements on their websites. The study was excluded representative offices of foreign banks and credit institutions. These banks represent very small percentage in total market share and most of them have very few branches, hence they were ignored from the analysis. The final sample comprises 18 commercial banks presented in Table 1. Most of these banks are listed on the Warsaw Stock Exchange.

Table 1. List of banks

\begin{tabular}{clc}
\hline No. & \multicolumn{1}{c}{ Name } & $\begin{array}{c}\text { Listed on the Warsaw Stock } \\
\text { Exchange as at 31 December } \\
\text { 2015 }\end{array}$ \\
\hline 1 & Alior Bank SA & Yes \\
2 & Bank BPH SA & Yes \\
3 & Bank Gospodarki Żywnościowej SA & Yes \\
4 & Bank Gospodarstwa Krajowego SA & No \\
5 & Bank Handlowy w Warszawie SA & Yes \\
6 & Bank Millennium SA & Yes \\
7 & Bank Ochrony Środowiska SA & Yes \\
8 & Bank Pekao SA & Yes \\
\hline
\end{tabular}




\begin{tabular}{clc}
\hline No. & \multicolumn{1}{c}{ Name } & $\begin{array}{c}\text { Listed on the Warsaw Stock } \\
\text { Exchange as at 31 December } \\
\mathbf{2 0 1 5}\end{array}$ \\
\hline 9 & Bank Pocztowy SA & No \\
10 & Bank Zachodni WBK SA & Yes \\
11 & Credit Agricole Bank Polska SA & No \\
12 & Getin Noble Bank SA & Yes \\
13 & ING Bank Śląski SA & Yes \\
14 & mBank SA & Yes \\
15 & Pekao Bank Hipoteczny SA & No \\
16 & Powszechna Kasa Oszczędności Bank & Yes \\
& Polski SA & No \\
17 & Raiffeisen Bank Polska SA & No \\
18 & SGB-Bank SA & \\
\hline
\end{tabular}

The data collected for the purpose of the study involves the examination of financial statements, management commentaries and corporate social responsibility reports for the years 2008-2015 of the population of the study. Therefore, the overall sample includes 144 bank-year observations. Table 2 lists the variables used in our models, required data and sources of information.

\section{Table 2. Variables, required data and data sources}

\begin{tabular}{|c|c|c|c|}
\hline $\begin{array}{c}\text { Variables } \\
\text { Dependent variables }\end{array}$ & Data & Data source & Previous studies \\
\hline $\begin{array}{l}\text { Average Return on } \\
\text { Assets (ROA) }\end{array}$ & $\begin{array}{l}\text { Net profit } \\
\text { Average of total } \\
\text { assets }\end{array}$ & $\begin{array}{l}\text { NSD, } \\
\text { Financial } \\
\text { statements }\end{array}$ & $\begin{array}{l}\text { Soana (2011); Wu \& Shen } \\
\text { (2013); Ofori et al., } \\
\text { (2014);Taskin (2015); } \\
\text { Cornett et al. (2016); Shen } \\
\text { et al. (2016) }\end{array}$ \\
\hline $\begin{array}{l}\text { Average Return on } \\
\text { Equity (ROE) }\end{array}$ & $\begin{array}{l}\text { Net profit } \\
\text { Average of total } \\
\text { equity }\end{array}$ & $\begin{array}{l}\text { NSD, } \\
\text { Financial } \\
\text { statements }\end{array}$ & $\begin{array}{l}\text { Soana (2011); Wu \& Shen } \\
\text { (2013); Ofori } \text { et al., } \\
\text { (2014); Taskin (2015); } \\
\text { Cornett et al. (2016); Shen } \\
\text { et al. (2016) }\end{array}$ \\
\hline $\begin{array}{l}\text { Net Interest Margin } \\
\text { (NIM) }\end{array}$ & $\begin{array}{l}\text { Net profit on } \\
\text { interests } \\
\text { Average of total } \\
\text { assets }\end{array}$ & $\begin{array}{l}\text { NSD, } \\
\text { Financial } \\
\text { statements }\end{array}$ & $\begin{array}{l}\text { Wu \& Shen (2013); } \\
\text { Taskin (2015); Shen et al. } \\
\text { (2016) }\end{array}$ \\
\hline $\begin{array}{l}\text { Independent variable } \\
\text { CSR disclosure index } \\
\text { (CSR) }\end{array}$ & $\begin{array}{l}\text { CSR disclosures } \\
\text { listed in } \\
\text { appendix A }\end{array}$ & $\begin{array}{l}\text { Management } \\
\text { commentaries } \\
\text { CSR reports }\end{array}$ & \\
\hline $\begin{array}{l}\text { Control variables } \\
\text { Net Log of Total } \\
\text { Assets (LogTA) }\end{array}$ & Total assets & $\begin{array}{l}\text { NSD, } \\
\text { Financial } \\
\text { statements }\end{array}$ & $\begin{array}{l}\text { Wu \& Shen (2013); Ofori } \\
\text { et al., 2014; Shen } \text { et al. } \\
\text { (2016); Cornett et al. } \\
\text { (2016) }\end{array}$ \\
\hline
\end{tabular}


An examination of the relationship between CSR disclosure and financial

performance: The case of Polish banks

\begin{tabular}{llll}
\hline $\begin{array}{c}\text { Variables } \\
\text { Dependent variables }\end{array}$ & Data & Data source & \multicolumn{1}{c}{ Previous studies } \\
\hline $\begin{array}{l}\text { Income Growth } \\
\text { (IncGrow) }\end{array}$ & Income & NSD, & $\begin{array}{l}\text { Ofori } \text { et al. }, \text { 2014; Cajias } \\
\text { et al. } \text { (2014); Chen \& }\end{array}$ \\
& & $\begin{array}{l}\text { Financial } \\
\text { statements }\end{array}$ & Wang, 2011 \\
$\begin{array}{l}\text { Leverage ratio } \\
\text { (Leverage) }\end{array}$ & Debt & NSD, & Weshah et al. (2012); Wu \\
& Total equity & $\begin{array}{l}\text { Financial } \\
\text { statements }\end{array}$ & $\begin{array}{l}\text { \& Shen (2013); Shen } \text { et al. } \\
(2016)\end{array}$ \\
\hline
\end{tabular}

The data are in two categories: (1) the financial data comprising the absolute values and the constructed ratios for the banks that constitute the subjects of this study, and (2) the CSR disclosure data used to calculate CSR index. The financial data of publicly listed banks were obtained from Notoria Serwis Database (NSD) ${ }^{i}$. For not listed banks the financial data were hand-collected from publicly available financial statements. The ratios were computed by the authors based on the collected data. The CSR disclosure data were hand collected from management commentaries and corporate social responsibility reports, which were available on banks' websites. The absolute values were standardized using their natural logarithms to make them appropriate for the linear regression analysis.

\subsection{Dependent variables - measures of bank financial performance}

To measure bank financial performance researchers, use two kinds of measurement approach which is accounting-based financial performance (e.g. Soana, 2011; Weshah, 2012; Wu \& Shen, 2013; Ofori et al., 2014; Taskin, 2015; Cornett et al., 2016; Shen et al. 2016) and market-based financial performance (e.g. Soana, 2011; Tafti et al., 2012).

In our analysis we consider financial performance from the accounting perspective and following the previous studies we use three measures of bank profitability, that are generally investigated: average Return on Assets (ROA), average Return on Equity (ROE) and Net Interest Margin (NIM).

ROA is the major ratio that indicates the profitability of a bank, which is defined as net profit over average total assets (ROA $=$ Net profit/Average of Total Assets). It measures the ability of the bank management to generate income by utilizing bank assets at their disposal. In other words, it shows how efficiently the resources of the bank are used to generate the income. According to Kohers \& Simpson (2002) ROA "measures the ability of bank managers to acquire deposits at a reasonable cost, invest these funds in profitable loans and investments, and profitably perform the daily operations of the bank".

ROE is also another financial ratio that indicates the profitability of a bank, which is calculated as net profit divided by average Total Equity Capital $(\mathrm{ROE}=\mathrm{Net}$ profit/Average of Total Equity Capital). It represents the rate of return earned on the funds invested in the bank by its stockholders. A bank that has a high return on equity 
is more likely to be one that is capable of generating cash internally. Thus, the higher the ROE the better the bank is in terms of profit generation.

NIM is a measure of the difference between the interest income generated by banks and the amount of interest paid on borrowed funds (for example, deposits), relative to the amount of their average assets. The NIM variable is defined as the net interest profit divided by average of total assets (NIM = Net profit on interest/Average of Total Assets). For most banks the largest amount of revenues comes from interest on loans. As a result, this kind of revenue affects net income and capital, which determine financial success (Kohers \& Simpson, 2002). The higher the net interest margin, the higher the bank's profit and the more stable the bank is. Thus, it is one of the key measures of bank profitability.

\subsection{Independent variable - measure of CSR}

There is no generally accepted method of measuring CSR activity of banks. Researchers have measured the CSR in diverse ways including the use of questionnaire surveys (Tafti et al., 2012), spending measures like sponsorships and donations (Adeyanju, 2012; Weshah et al., 2012), content analysis of disclosed CSR information in CSR reports (Taskin, 2015), unidimensional, and multidimensional ratings based on some observable social responsibility indicators, such as KLD ratings (Becchetti et al., 2012), EIRIS Index (Wu \& Shen, 2013), AEI Index (Soana, 2011), and SGP Index (Torres et al., 2012). In this study to measure CSR disclosures we used content analysis and we have developed aggregated CSR index.

International regulations related to CSR distinguish the different areas of social responsibility, for example, ISO 26000 norm (2012) stands 7 areas: organizational governance, human rights, labour practices, the environment, fair operating practices, consumer issues and community involvement and development. Global Compact Principles focuses on responsibility in the area of human rights, labour standards, the environment and anti-corruption activities. The GRI guidelines include specific indicators divided into three categories: economic, social and environmental. Categories are divided into aspects, and for example, social category includes employment, labelling of products and services, human rights.

In the banking sector the most important are relations with employees, customers, investors, the environment and the local community (Krasodomska, 2012). Prior empirical studies have categorized CSR into different sub themes, for instance, Gray et al. (1995b) have classified the CSR disclosure as human resource, environmental, community, and customer; Kiliç et al. (2015) as environment, energy, human resources, products and customers, and community involvement. Thus, CSR disclosure has been classified into sub four themes in this research as environment, 
human resources, products and customers, and community involvement (see Appendix A).

In line with earlier studies, to measure the level of CSR reporting in commercial banks, content analysis method has been applied. The study analysed the existence or absence of particular CSR disclosures in corporate reports, namely management commentary, annual report, CSR report, sustainability report, environmental report. The study used the approach of assigning a value of 1 if an item of CSR disclosures is reported and 0 if it is not, no matter the communication channel. For example, if the disclosure item was presented in two or more reports by some bank the presence of the item was treated once. The CSR reporting index for each bank is calculated as follows:

where:

$$
\text { CSR reporting index }=\frac{\sum_{i=1}^{n} x_{i}}{n}
$$

$x i-1$ if the item $i$ is disclosed, 0 if the item $i$ is not disclosed,

$n$ - number of items.

The overall level of CSR reporting has been measured for the four areas, namely Environment, Human Resources, Products and Customers, Community Involvement.

In order to improve the predictive capability of the regression models proposed in the research, the CSR reporting index was properly lagged which permitted the testing of the causal relationship between the CSR and the FP. The causality testing through the appropriate lagging of the CSR as independent variable is a growing feature of the current literature (Cajias et al. 2014; Sun \& Cui, 2014; Nollet et al. 2016). This is in line with the assumption that CSR is an investment in intangible asset that takes some time to generate the expected returns (Jiao, 2010).

\subsection{Control variables}

In the most of recent studies researchers incorporated different control variables in their models, such as size, banking risk, management preference, firm growth, earnings, industry and year. In our study, we include three control variables that occurred most in the empirical literature and that have been hypothesized to be correlated with banks' financial performance: the size, the risk and the growth. In terms of operationalization, the size was measured as the absolute value of the total assets but standardized by natural logarithm. In order to control for risk, we used leverage ratio defined as the debts to total equity (Leverage ratio $=$ Debts/Total Equity). The growth was measured as the income growth. 
Consistent with the current literature, we expect that banks' financial performance is positively associated with total assets (Ofori et al., 2014) and income growth (Chen \& Wang, 2011), while it is negatively associated with leverage ratio (Wu \& Shen, 2013).

\subsection{The models - effects of CSR disclosures on banks financial performance}

To examine the effect of CSR disclosure on banks' financial performance, we estimate a panel data models.

Panel data typically refers to a particular type of multilevel data. Measurement at over time (T1, T2, T3...) is nested within subjects, for example firms. Each time is referred to as a "wave", so panel datasets are described in terms of the number of individual cases $(\mathrm{N})$, and the number of waves $(\mathrm{T})$. Panel data analysis is a useful method of research in contemporary social and economic studies. Panel data have several advantages over the one-dimensional data. First, find use in the testing of causality. Besides, based on this data it is easier to verify hypotheses, to eliminate the bias and reduce the problems associated with multicollinearity (Kopczewska et al., 2009).

The proposed models are given as:

$$
\begin{aligned}
& R_{\text {OA }} \text { it }=\beta_{0}+\beta_{1} \text { LogTA }_{i t}+\beta_{2} \text { IncGrow }_{i t}+\beta_{3} \text { Leverage }_{i t}+\beta_{4} \text { CSR }_{i t-1}+\varepsilon_{i t} \\
& \text { ROE }_{i t}=\beta_{0}+\beta_{1} \text { LogTA }_{i t}+\beta_{2} \text { IncGrow }_{i t}+\beta_{3} \text { Leverage }_{i t}+\beta_{4} \text { CSR }_{i t-1}+\varepsilon_{i t} \\
& \text { NIM }_{i t}=\beta_{0}+\beta_{1} \text { LogTA }_{i t}+\beta_{2} \text { IncGrow }_{i t}+\beta_{3} \text { Leverage }_{i t}+\beta_{4} \text { CSR }_{i t-1}+\varepsilon_{i t}
\end{aligned}
$$

where,

$\mathrm{ROA}_{\mathrm{it}}$ - average Return on Assets of Bank $i$ at time $t$,

$\mathrm{ROE}_{\text {it }}$ - average Return on Equity of Bank $i$ at time $t$,

$\mathrm{NIM}_{\mathrm{it}}$ - Net Interest Margin of Bank $i$ at time $t$,

$\operatorname{LogTA} \mathrm{At}_{\mathrm{it}}$ - natural logarithm of total assets of Bank $i$ at time $t$,

IncGrow $_{\text {it }}$ - income growth of Bank $i$ at time $t$,

Leverage $_{\mathrm{it}}-$ leverage ratio of Bank $i$ at time $t$,

$\mathrm{CSR}_{\mathrm{it}-1}$ - lagged CSR index,

$\beta_{0}$ - an intercept,

$\beta_{1 \ldots 4}-$ a vector of exogenous variables and observations,

$\varepsilon$ - a random component (errors),

$\mathrm{i}=1,2, \ldots, \mathrm{N}$, index of bank,

$\mathrm{t}=1,2, \ldots, \mathrm{T}$, index of time.

Three basic types of models: pooled models (OLS), fixed effects models (FE) and random effects models (RE) were used to model panel data in the study. First, F-test was applied to determine which method performed best one to choose between 
pooled OLS and fixed-effect. In addition, in the case of the FE model with timefixed effects, the Wald test was conducted to examine the impact of temporary variables. In the next stage of the analysis, the Breusche and Pagan Lagrange multiplier test was employed to decide whether the pooled OLS model or the random effect model was appropriate for the study. In addition, the fixed-effects model and the random-effects model were compared by using the Hausman's test. This procedure was repeated for each dependent variable ROA, ROE or NIM.

The results of the analyses are presented and discussed below.

\section{Results and interpretation}

\subsection{Trend analysis of CSR reporting level and FP of Banks}

The overall level of CSR reporting has been measured for the four areas, namely Environment (ENV), Human Resources (HR), Products and Customers (P\&C), Community Involvement (CI). The reporting level of each CSR area is illustrated in Figure 1. The CSR reporting level is increasing over the years in all areas. This is a positive trend in the Polish banking sector. The commercial banks strongly improve the reporting on CSR. According to the figure, Community Involvement level exceeds $60 \%$ in 2014 and is well above the other areas throughout 2007-2014. This demonstrates the strong commitment of the banks in charity, volunteer and sponsorship. Besides, $\mathrm{HR}$ and $\mathrm{P} \& \mathrm{C}$ are quite close to each other in terms of reporting level that increased from $15 \%$ to approximately $50 \%$ during the examined period. The banks also show concern for the environment. Although Environment is the least reported area, it shows an upward trend. From 2007 until 2014, this level increased from $13 \%$ to $31 \%$. The banks have still much to do to improve the level of reporting especially in the area of Environment.

Figure 2 illustrates development of profitability ratios throughout 2008-2015. Level of ROE for the banking sector changed dramatically from above 8 in 2008 to below 4 in 2015. Level of ROA and NIM were stable over study period and become around 0.5 and 2 respectively. Taking into consideration world economic crisis in 2008, it should be stated that Polish banking system was not affected by the crisis as much as we should expect. This is presented in very stable development of ROA and NIM. This situation could affect the relation between CSR and profitability ratios. 
Figure 1. CSR reporting levels

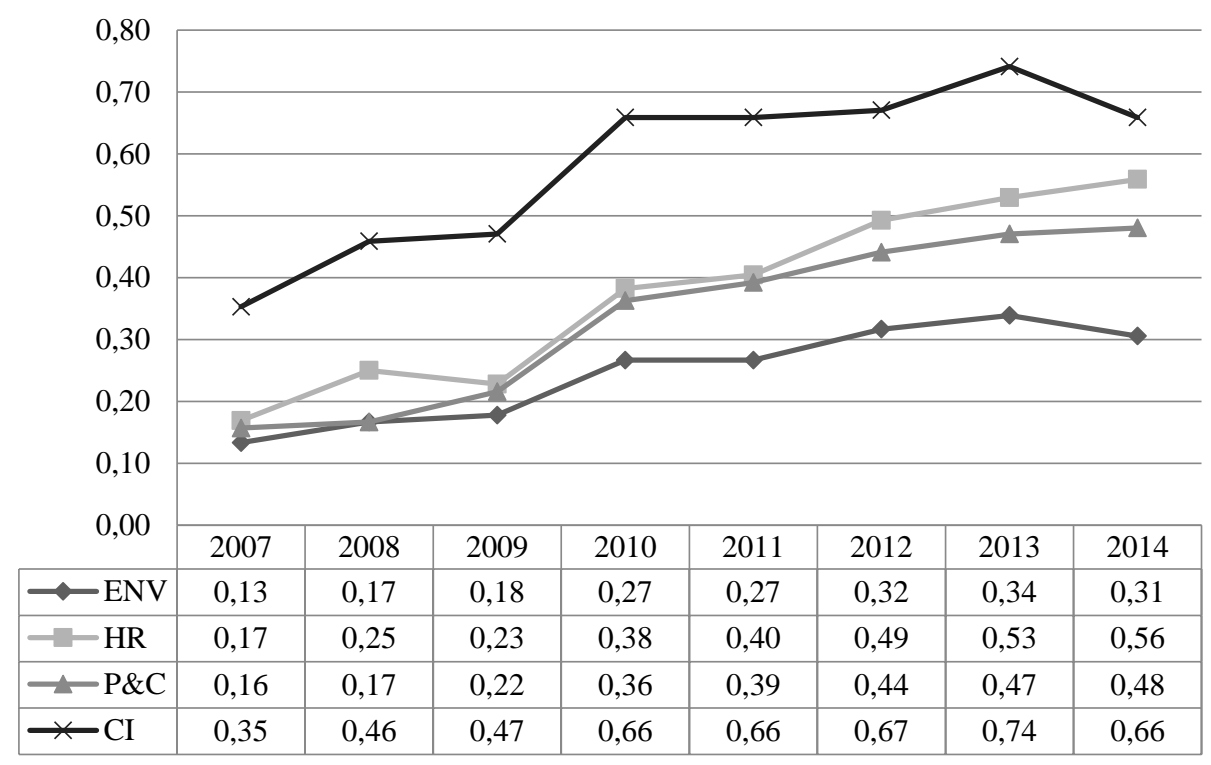

Figure 2. Development of performance measures

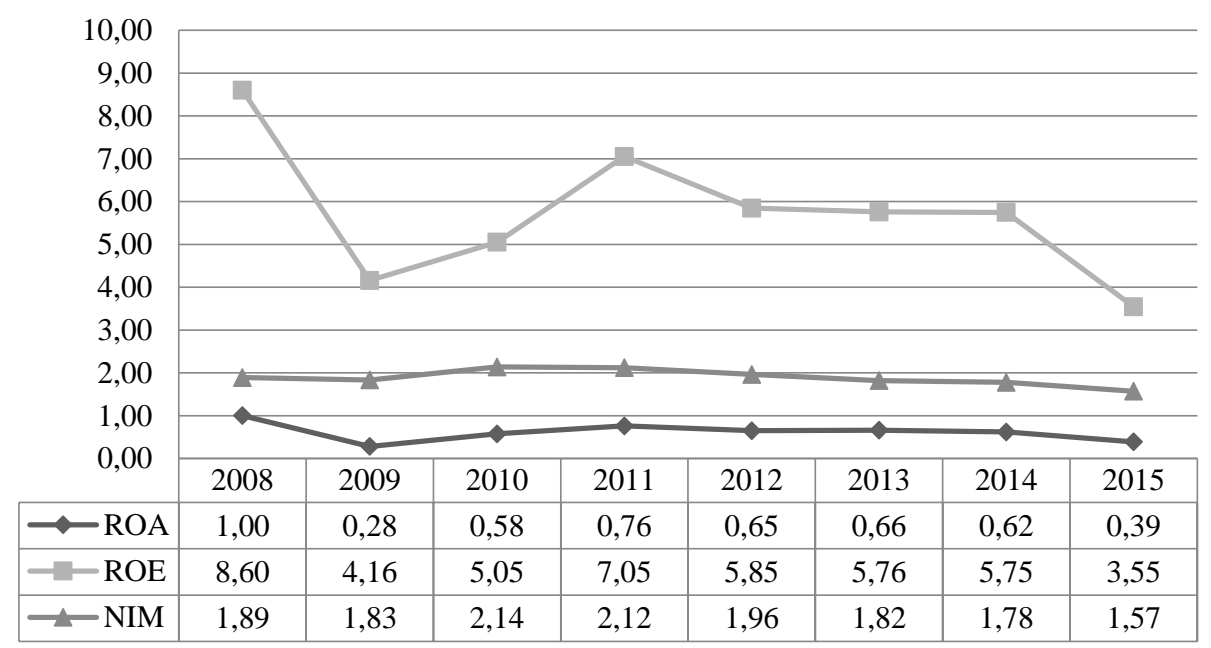

\subsection{Descriptive statistics}

Table 3 presents descriptive statistics for dependent, independent and controlled variables used in regression analysis. The mean score for ROA is $0.96 \%$ and standard 
deviation of $1.04 \%$. This suggests that over the study period ROA for the banks averages about $96 \%$ with individual yearly figures differing around $1.04 \%$. Variations for ROA as indicated by the standard deviation are confirmed by the minimum and maximum values of $-6.43 \%$ and $6.15 \%$ respectively. ROE registers a mean of $8.95 \%$ with very high standard deviation of $6.48 \%$. This can be confirmed by high variability of ROE on figure 2 . This suggest that banks are keen to generate about $885 \%$ return on for shareholders' investments. The mean score for NIM $(2.94 \%)$ is higher than ROA and the variability over this value is also very high, as indicated by its standard deviation of $(1.71 \%)$. The average growth in the banks during the analysed period was about $104.82 \%$ as indicated by the mean. This suggest incredible development in banking sector. Further, the average level of leverage suggests that an average bank has about $9.40 \%$ of equity as total liabilities. This confirms Saunders \& Cornett's (2008) suggestion that banks are generally risky companies. The aggregated CSR mean (33.99\%) suggests that banks rather do not regard their CSR activities as strategically oriented. High figure of standard deviation $(27.77 \%)$ indicating significant differences in CSR activities among banks in Poland. This supports the thesis that CSR activities in banking industry in Poland are on early stage.

Table 3. Descriptive statistics

\begin{tabular}{lrrrrrrr}
\hline \multicolumn{1}{c}{ Variable } & Minimum & Maximum & Mean & Median & $\begin{array}{c}\text { Std. } \\
\text { Deviation }\end{array}$ & Kurtosis & Skewness \\
\hline ROA (\%) & -6.43 & 6.15 & 0.96 & 0.915 & 1.04 & 20.37 & -1.61 \\
ROE (\%) & -22.44 & 25.38 & 8.95 & 9.54 & 6.48 & 3.48 & -0.73 \\
NIM (\%) & 0,23 & 11.27 & 2.94 & 2.65 & 1.71 & 8.00 & 2.51 \\
LogTA & 0.56 & 5.59 & 3.41 & 3.61 & 1.20 & -0.12 & -0.64 \\
IncGrow (\%) & -0.06 & 593.66 & 104.82 & 95.52 & 46,67 & 82.31 & 8.15 \\
Leverage (\%) & 0.31 & 20.21 & 9.46 & 8.82 & 4.04 & 0.44 & 0.87 \\
CSR (\%) & 0.00 & 100.00 & 33,99 & 28.00 & 27.77 & -0.72 & 0.57 \\
\hline
\end{tabular}

\subsection{Pearson correlation analysis}

Table 4 presents correlation between variables. Correlation explores the bivariate relationships among the variables. Almost half of the correlation coefficients are less than 0.5 except for the value 0.799 between ROA and ROE. The results of the low correlations among selected independent variables may remove the problem multicollinearity in our model. As a rule of thumb, if the largest variance inflation factor (VIF) is greater than 10, there is evidence of collinearity. VIF figures depicted in table 2 are below 10, which confirm the absence of multicollinearity between variables in this study.

According to the results, there is a low positive insignificant correlation between ROA, ROE and CSR (0.079, p-value >0.05; 0.047, p-value >0,05) and negative 
insignificant correlation between NIM and CSR (-0,006; p-value>0,05). Significant positive correlation is observed between LogTA and ROA and ROE. IncGow is positively and insignificantly correlated with ROE and negatively correlated with ROA and NIM. Leverage is negatively significantly correlated with ROA and NIM.

Because of constraints of bivariate analysis in next step of the research we employed panel data analysis.

Table 4. Correlation matrix of variables

\begin{tabular}{|c|c|c|c|c|c|c|c|c|}
\hline & VIF & ROA & ROE & NIM & LogTA & IncGrow & Leverage & CSR \\
\hline ROA (\%) & & 1 & & & & & & \\
\hline ROE (\%) & & $0.799 * *$ & 1 & & & & & \\
\hline NIM (\%) & & 0.109 & 0.092 & 1 & & & & \\
\hline $\log \mathrm{TA}$ & 1.304 & $0.239 * *$ & $0.340 * *$ & -0.056 & 1 & & & \\
\hline $\begin{array}{l}\text { IncGrow } \\
(\%)\end{array}$ & 1.042 & -0.075 & 0.146 & -0.094 & -0.128 & 1 & & \\
\hline $\begin{array}{l}\text { Leverage } \\
(\%)\end{array}$ & 1.040 & $-0.293 * *$ & -0.012 & $-0.200 * *$ & -0.131 & 0.076 & 1 & \\
\hline $\operatorname{CSR}(\%)$ & 1.354 & 0.079 & 0.047 & -0.006 & $0.480 * *$ & $-0.194 * *$ & $-0.185 * *$ & 1 \\
\hline
\end{tabular}

** Correlation significant at the 0.05 level

\subsection{Panel data analysis}

Table 5 depicts estimated coefficients from panel data analysis for ROA as dependant variable. First, we estimated OLS model and employed F-test in order to determine which model (the pooled OLS model or the fixed effects model) to employ. The estimated model has the form:

$$
\widehat{R O A}=b_{0}+b_{1} \log T A+b_{2} \text { IncGrow }+b_{3} \text { Leverage }+b_{4} C S R
$$

The results of F-test indicated that (2.470; p-value $<0.01)$ the fixed effects model was appropriate to use rather than the pooled OLS model. Among FE models, the least square dummy variable model (LSDV) was employed to understand the fixed effects. The effect of independent variables is mediated by the differences between banks. The pure effect of independent variables was estimated by adding a dummy for each bank. Each dummy absorbs the effects peculiar to each bank. In addition, it is worth noting that in the case of the FE model with time-fixed effects, the impact of temporary variables was observed, which confirms the Wald test (15.400; pvalue $<0.05$ ). In addition, the Breusch and Pagan Lagrangian multiplier test for random effects indicated which model to choose between a random effects regression and a simple OLS regression. According to the Breush-Pagan test result 
(0.881, p-value >0.10), the simple OLS regression was not preferable than the random effect model. In addition, we employed the Hausman's test statistics $(17.395 ;$ p-value $<0.01)$ to confirm that the fixed effects model was preferable compared with random-effects model. After running the necessary tests for choosing the right model, the fixed effect model with time-fixed effects was the most appropriate model for this research study. Therefore, the results of the fixed effect model with time-fixed effects were taken into consideration for further discussion.

According to the results presented in table 5, CSR coefficient (b4=0,0048) was positive implying that greater efforts aimed at improving CSR index might lead to some improvement in the ROA ratio. Thus, the first hypothesis (H1) can be accepted. However, beta of CSR index did not appear to be tangible, because its p-value is not significant ( $\mathrm{p}$-value>0.05). Therefore, the fourth hypothesis $(\mathrm{H} 4)$ is rejected.

Table 5. Estimated coefficients from the panel data analysis, years 2008 - 2015 ROA (dependent variable)

\begin{tabular}{|c|c|c|c|c|}
\hline \multirow{2}{*}{$\begin{array}{l}\text { Independent } \\
\text { variables }\end{array}$} & \multirow{2}{*}{$\begin{array}{l}\text { Pooled model } \\
\text { OLS }\end{array}$} & \multicolumn{2}{|c|}{ Fixed effects models } & \multirow{2}{*}{$\begin{array}{l}\begin{array}{l}\text { Random } \\
\text { effects } \\
\text { model }\end{array} \\
\text { RE }\end{array}$} \\
\hline & & FE (LSDV) & $\begin{array}{l}\text { FE model } \\
\text { with time- } \\
\text { fixed effects }\end{array}$ & \\
\hline CSR (\%) & $\begin{array}{l}-0.004 \\
(-1.067)\end{array}$ & $\begin{array}{l}0.006 \\
(1.213)\end{array}$ & $\begin{array}{l}0.0048 \\
(0.983)\end{array}$ & $\begin{array}{l}-0.002 \\
(-0.622)\end{array}$ \\
\hline LogTA & $\begin{array}{l}\text { 0.211*** } \\
(2.716)\end{array}$ & $\begin{array}{l}-\mathbf{- 0 . 7 3 9} * * * \\
(-3.041)\end{array}$ & $\begin{array}{l}\mathbf{- 0 . 6 9 2 * *} \\
(-2.162)\end{array}$ & $\begin{array}{l}0.146 \\
(1.534)\end{array}$ \\
\hline IncGrow (\%) & $\begin{array}{l}0.0009 \\
(-0.519)\end{array}$ & $\begin{array}{l}-0.004 \\
(-2.117)\end{array}$ & $\begin{array}{l}-0.002 \\
(-1.267)\end{array}$ & $\begin{array}{l}-0.001 \\
(-0.663)\end{array}$ \\
\hline Leverage $(\%)$ & $\begin{array}{l}-\mathbf{- 0 . 0 7 1} * * * \\
(-3.424)\end{array}$ & $\begin{array}{l}0.013 \\
(0.303)\end{array}$ & $\begin{array}{l}0.0004 \\
(0.09)\end{array}$ & $\begin{array}{l}\mathbf{- 0 . 0 7 2} \text { **** } \\
(-2.966)\end{array}$ \\
\hline Constant & $\begin{array}{l}\mathbf{1 . 1 3 0} * * * \\
(2.877)\end{array}$ & $\begin{array}{l}\text { 3.591 } * * * \\
(4.760)\end{array}$ & $\begin{array}{l}\text { 3.779*** } \\
(4.521)\end{array}$ & $\begin{array}{l}\mathbf{1 . 3 4 5}^{* * * *} \\
(2.967)\end{array}$ \\
\hline T_2009 & & & $\begin{array}{l}\mathbf{- 0 . 9 5 9} * * * \\
(-3.120)\end{array}$ & \\
\hline T_2010 & & & $\begin{array}{l}-\mathbf{- 0 . 5 3 0} * \\
(-1.700)\end{array}$ & \\
\hline T_2011 & & & $\begin{array}{l}-0.071 \\
(-0.218)\end{array}$ & \\
\hline T_2012 & & & $\begin{array}{l}-0.299 \\
(-0.845)\end{array}$ & \\
\hline T_2013 & & & $\begin{array}{l}-0.222 \\
(-0.601)\end{array}$ & \\
\hline T_2014 & & & $\begin{array}{l}-0.255 \\
(-0.646)\end{array}$ & \\
\hline
\end{tabular}


ROA (dependent variable)

\begin{tabular}{|c|c|c|c|c|}
\hline \multirow{2}{*}{$\begin{array}{l}\text { Independent } \\
\text { variables }\end{array}$} & Pooled model & \multicolumn{2}{|c|}{ Fixed effects models } & \multirow{2}{*}{$\begin{array}{l}\text { Random } \\
\text { effects } \\
\text { model } \\
\text { RE }\end{array}$} \\
\hline & OLS & FE (LSDV) & $\begin{array}{l}\text { FE model } \\
\text { with time- } \\
\text { fixed effects }\end{array}$ & \\
\hline T_2015 & & & $\begin{array}{l}-0.582 \\
(-1.411)\end{array}$ & \\
\hline $\mathrm{N}$ & 144 & 144 & 144 & 144 \\
\hline $\mathrm{R}^{2}$ & 0.135 & 0.356 & 0.432 & 0.145 \\
\hline $\begin{array}{l}\text { Test Breusha- } \\
\text { Pagana }\end{array}$ & & & & 0.881 \\
\hline F Test & & $2.470 * * *$ & $2.253 * * *$ & \\
\hline Test Hausmana & & & & $17.395 * * *$ \\
\hline Test Walda & & & $15.400 * *$ & \\
\hline
\end{tabular}

$t$ statistics in parentheses; $* \mathrm{p}<0.10, * * \mathrm{p}<0.05, * * * \mathrm{p}<0.01$

LogTA (b1=-0.692) showed negative significant relationship with ROA, IncGrow (b2=-0.002) showed negative insignificant relationship and Leverage (b3=0.0004) showed positive insignificant relationship with ROA. This insignificant impact of variables implied that their beta values might be due to chances and might not be significantly different from 0 . The provided independent variables explained almost $43.2 \%$ of the variation in the ROA variable.

Similar model selection procedure was undertaken for ROE and NIM. The estimated OLS models were as follows:

$$
\begin{aligned}
& \widehat{R O E}=b_{0}+b_{1} \text { LogTA }+b_{2} \text { IncGrow }+b_{3} \text { Leverage }+b_{4} C S R \\
& \widehat{N I M}=b_{0}+b_{1} \text { LogTA }+b_{2} \text { IncGrow }+b_{3} \text { Leverage }+b_{4} C S R
\end{aligned}
$$

Table 6 depicts estimated coefficients from panel data analysis for ROE as dependant variable. After employed following tests F-test (4.148; p-value<0.01), Breush-Pagan test (17.98; p-value $<0.01)$, Wald test $(31.57$; p-value $<0.01)$, and Hausman test (13.95; p-value $<0.1)$, the fixed effects model with time fixed effects was the most appropriate model for ROE. Therefore, the results of this model were taken into consideration for further discussion.

According to the results presented in table 6, CSR coefficient had a positive effect on ROE (b4=0,025), thus the second hypothesis (H2) can be accepted. However, there was not any statistical significance between CSR and ROE ( $p>0.05)$, therefore 
the fifth hypothesis (H5) is rejected. Control variables such as IncGrow (b2=0.023; p-value $<0.05)$ had a positive and statistically insignificant effect on the dependent variable ROE. LogTA (b1=-0.985; p-value $>0.05$ ) had a negative and statistically insignificant effect on the dependent variable ROE. Leverage (b3=0.300; pvalue $>0.05$ ) had a positive and statistically insignificant effect on the dependent variable ROE.

In addition, the results also indicate, that time had a significant impact on the ROE. The extent to which each year affected ROE show variables T_2009, T_2010, T_2011, T_2012, T_2013, T_2014, T_2015. The point of reference is the year 2008. For example, in 2009 banks on average reported lower level of ROE comparing with 2008 by $-6.915 \%$ (p-value $<0.01$ ). In 2015, banks on average, reported lower level of ROE comparing with 2008 by $-7.610 \%$ (p-value $<0.01$ ). These results can be confirmed visibly by the development of ROE ratio presented on figure 2 . The provided independent variables explained almost $58.3 \%$ of the variation in the dependent variable.

Table 7 depicts estimated coefficients from panel data analysis for NIM as dependant variable. After employed following tests F-test (25.79; p-value $<0.01)$, Breush-Pagan test (347.72; p-value $<0.01)$, Wald test (21.83; p-value<0.05), and Hausman test (0.93; p-value $>0.1)$, the random effect model was the most appropriate model for NIM. Therefore, the results of this model were taken into consideration for further discussion

According to the results presented in table 7, CSR had a negative effect on NIM (b4=-0.006), thus the third (H3) and must be rejected. However, the relation between CSR and NIM is statistically significant ( $\mathrm{p}$-value $<0.05)$, therefore the sixth hypothesis (H6) is accepted. All the control variables: IncGrow (b2=-0.002), Leverage (b3=-0.071) and LogTA (b1=-0.168), showed negative relationship with NIM. Among control variables beta coefficients Leverage (p-value $<0.05)$ was statistically significant whereas beta coefficients of IncGrow (p-value $>0.1)$ and LogTA (p-value $>0.1$ ) were not significant. The provided independent variables explained only $7.4 \%$ of the variation in the dependent variable. 
Table 6. Estimated coefficients from the panel data analysis, years 2008 - 2015

ROE (dependent variable)

\begin{tabular}{|c|c|c|c|c|}
\hline \multirow{2}{*}{$\begin{array}{l}\text { Independent } \\
\text { variables }\end{array}$} & \multirow{2}{*}{$\begin{array}{l}\text { Pooled model } \\
\text { OLS }\end{array}$} & \multicolumn{2}{|c|}{ Fixed effects models } & \multirow{2}{*}{ 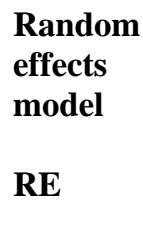 } \\
\hline & & FE (LSDV) & $\begin{array}{l}\text { FE model } \\
\text { with time- } \\
\text { fixed effects }\end{array}$ & \\
\hline CSR & $\begin{array}{l}-0.028 \\
(-1.329)\end{array}$ & $\begin{array}{l}0.020 \\
(0.748)\end{array}$ & $\begin{array}{l}0.025 \\
(0.943)\end{array}$ & $\begin{array}{l}-0.014 \\
(-0.615)\end{array}$ \\
\hline $\operatorname{LogTA}$ & $\begin{array}{l}\mathbf{2 . 2 6 5} * * * \\
(4.734)\end{array}$ & $\begin{array}{l}\mathbf{- 3 . 0 1 0 * *} \\
(-2.185)\end{array}$ & $\begin{array}{l}-0.985 \\
(-0.575)\end{array}$ & $\begin{array}{l}\mathbf{1 . 2 7 7 *} \\
(1.786)\end{array}$ \\
\hline IncGrow (in \%) & $\begin{array}{l}\mathbf{0 . 0 2 4} * * \\
(2.220)\end{array}$ & $\begin{array}{l}0.009 \\
(0.833)\end{array}$ & $\begin{array}{l}\mathbf{0 . 0 2 3} * * \\
(2.179)\end{array}$ & $\begin{array}{l}\mathbf{0 . 0 2 2} * * \\
(2.106)\end{array}$ \\
\hline Leverage & $\begin{array}{l}0.003 \\
(0.022)\end{array}$ & $\begin{array}{l}\mathbf{0 . 5 6 9} * * \\
(2.322)\end{array}$ & $\begin{array}{l}0.300 \\
(1.171)\end{array}$ & $\begin{array}{l}0.063 \\
(0.377)\end{array}$ \\
\hline Constant & $\begin{array}{l}-0.417 \\
(-0.173)\end{array}$ & $\begin{array}{l}\text { 12.234**** } \\
(2.285)\end{array}$ & $\begin{array}{l}\mathbf{1 0 . 6 2 6}^{* *} \\
(2.375)\end{array}$ & $\begin{array}{l}2.198 \\
(0.703)\end{array}$ \\
\hline T_2009 & & & $\begin{array}{l}\mathbf{- 7 . 6 1 0} * * * \\
(-4.626)\end{array}$ & \\
\hline T_2010 & & & $\begin{array}{l}\mathbf{- 5 . 3 0 8} * * * \\
(-3.180)\end{array}$ & \\
\hline T_2011 & & & $\begin{array}{l}-2.593 \\
(-1.479)\end{array}$ & \\
\hline T_2012 & & & $\begin{array}{l}\mathbf{- 3 . 8 9 8} * * \\
(-2.058)\end{array}$ & \\
\hline T_2013 & & & $\begin{array}{l}-4.173 * * \\
(-2.113)\end{array}$ & \\
\hline T_2014 & & & $\begin{array}{l}\mathbf{- 4 . 0 1 2} * \\
(-1.896)\end{array}$ & \\
\hline T_2015 & & & $\begin{array}{l}\mathbf{- 7 . 4 8 8} * * * \\
(-3.393)\end{array}$ & \\
\hline $\mathrm{N}$ & 144 & 144 & 144 & 144 \\
\hline $\mathrm{R}^{2}$ & 0.162 & 0.469 & 0.583 & 0.176 \\
\hline Test Breusha-Pagana & & & & $17.98 * * *$ \\
\hline F Test & & $4.148 * * *$ & $4.28 * * *$ & \\
\hline Test Hausmana & & & & $13.95 * * *$ \\
\hline Test Walda & & & $31.57 * * *$ & \\
\hline
\end{tabular}


An examination of the relationship between CSR disclosure and financial performance: The case of Polish banks

Table 7. Estimated coefficients from the panel data analysis, years 2008 - 2015

NIM (dependent variable)

\begin{tabular}{|c|c|c|c|c|}
\hline \multirow{2}{*}{$\begin{array}{l}\text { Independent } \\
\text { variables }\end{array}$} & \multirow{2}{*}{$\begin{array}{l}\text { Pooled model } \\
\text { OLS }\end{array}$} & \multicolumn{2}{|c|}{ Fixed effects models } & \multirow{2}{*}{$\begin{array}{l}\text { Random } \\
\text { effects } \\
\text { model } \\
\text { RE }\end{array}$} \\
\hline & & FE (LSDV) & $\begin{array}{l}\text { FE model } \\
\text { with time- } \\
\text { fixed effects }\end{array}$ & \\
\hline CSR & $\begin{array}{l}-0.001 \\
(-0.223)\end{array}$ & $\begin{array}{l}\mathbf{- 0 . 0 0 7 * *} \\
(-2.037)\end{array}$ & $\begin{array}{l}0.002 \\
(0.565)\end{array}$ & $\begin{array}{l}\mathbf{- 0 . 0 0 6 * *} \\
(-1.965)\end{array}$ \\
\hline $\log T A$ & $\begin{array}{l}-0.121 \\
(-0.901)\end{array}$ & $\begin{array}{l}0.223 \\
(1.228)\end{array}$ & $\begin{array}{l}0.968 * * * \\
(4.668)\end{array}$ & $\begin{array}{l}-0.168 \\
(-1.042)\end{array}$ \\
\hline IncGrow (in \%) & $\begin{array}{l}-0.003 \\
(-1.102)\end{array}$ & $\begin{array}{l}-0.002 \\
(-1.461)\end{array}$ & $\begin{array}{l}\mathbf{- 0 . 0 0 2} * \\
(-1.843)\end{array}$ & $\begin{array}{l}-0.002 \\
(-1.633)\end{array}$ \\
\hline Leverage & $\begin{array}{l}\mathbf{- 0 . 0 8 8} * * \\
(-2.469)\end{array}$ & $\begin{array}{l}\mathbf{- 0 . 0 7 5} * * \\
(-2.338)\end{array}$ & $\begin{array}{l}\mathbf{- 0 . 1 5 0} * * * \\
(-4.819)\end{array}$ & $\begin{array}{l}\mathbf{- 0 . 0 7 1} * * \\
(-2.375)\end{array}$ \\
\hline Constant & $\begin{array}{l}\text { 4.590**** } \\
(6.762)\end{array}$ & $\begin{array}{l}\text { 3.349 } * * * \\
(5.942)\end{array}$ & $\begin{array}{l}\text { 1.717**** } \\
(3.167)\end{array}$ & $\begin{array}{l}\mathbf{3 . 5 0 0}^{*} * * * \\
(7.595)\end{array}$ \\
\hline T_2009 & & & $\begin{array}{l}-0.141 \\
(0.706)\end{array}$ & \\
\hline T_2010 & & & $\begin{array}{l}0.125 \\
(0.620)\end{array}$ & \\
\hline T_2011 & & & $\begin{array}{l}-0.012 \\
(-0.057)\end{array}$ & \\
\hline T_2012 & & & $\begin{array}{l}-0.545 * * \\
(-2.377)\end{array}$ & \\
\hline T_2013 & & & $\begin{array}{l}\mathbf{- 0 . 8 2 0} * * * \\
(-3.430)\end{array}$ & \\
\hline T_2014 & & & $\begin{array}{l}\mathbf{- 1 . 0 3 6} \text { **** } \\
(-4.041)\end{array}$ & \\
\hline T_2015 & & & $\begin{array}{l}\mathbf{- 1 . 4 1 9} * * * \\
(-5.310)\end{array}$ & \\
\hline $\mathrm{N}$ & 144 & 144 & 144 & 144 \\
\hline $\mathrm{R}^{2}$ & 0.055 & 0.913 & 0.866 & 0.074 \\
\hline Test Breusha-Pagana & & & & $347,72 * * *$ \\
\hline F Test & & $25.79 * * *$ & $29.21 * * *$ & \\
\hline Test Hausmana & & & & 0.93 \\
\hline Test Walda & & & $21.83 * *$ & \\
\hline
\end{tabular}

$t$ statistics in parentheses; $* \mathrm{p}<0.10, * * \mathrm{p}<0.05, * * * \mathrm{p}<0.01$ 


\section{Conclusions}

\subsection{Conclusions and recommendations}

The purpose of this study is twofold. First, this study investigates the trend of corporate social responsibility (CSR) reporting and financial performance (FP) in commercial banks in Poland. Second, this study examines the impact of the CSR disclosures of the banks on their financial performance (ROA, ROE, NIM).

The CSR reporting level was increasing over the years in all areas. This is a positive trend in the Polish banking sector. Despite the fact that development of ROA and NIM were stable in analysed period, the level of ROE for the banking sector was changing dramatically. Taking into consideration world economic crisis in 2008, it should be stated that Polish banking system was not affected by the crisis as much as we should expect. This situation could affect the relation between CSR and profitability ratios.

Literature review conducted in section 2, revealed that previous studies reported divergent findings on the nature and the strength of the effects of the CSR activities on the financial performance of companies. The results of the prior studies include those with: strong positive effects, strong negative effects, neutral effects, and mixed effects. This study showed mixed effects of the CSR on the financial performance, depending on the particular model tested. The interpretations of the findings were also not consistent.

The study revealed a positive relationship between banks' CSR disclosures and their profitability measured by ROA and ROE. Similar results were reported by Dumitrescu and Simionescu (2015) who based on Romanian listed companies. However, the relationship between banks' CSR disclosures and NIM is negative. In this last case, the negative effect was interpreted in the literature as expressing either the shareholders' confidence in the firm and their preparedness to accept lower returns in the short run or in alignment with their private social responsibility values (Jenson, 2010) or as expressing the presence of managerial opportunism (Jiao, 2010).

Consistent, with the previous literature on the relation between the CSR and financial performance and the insights from the stakeholder theory, we hypothesized that the CSR index had significant positive effect on the accounting returns. In conflict with our hypotheses, we found that CSR did not significantly predict accounting returns.

Employed panel analysis did not report any significant effect of the banks' CSR activities on the accounting returns measured by ROA, ROE and NIM. This result was consistent with findings of Soana (2011), in which no significant effect was observed between the CSR and accounting returns. Conversely, our findings on the 
absence of significant relation between CSR and FP were at variance with Adeyanju, (2012), Ofiri et al. (2014), Tafti et al. (2012) and Weshah et al. (2012). In these studies, researchers found significant positive effects of the CSR on the accounting returns.

Moreover, the effect of the control variables on the accounting returns was observed but it was statistically insignificant. The regression results showed that CSR activities undertaken by banks are not dominant predictor of their profitability as compared with their control variables (LogTA, IncGrow, Leverage). Therefore, banks engaging in CSR practices should do so in conjunction with other factors which have a significant impact on financial performance.

The above-mentioned findings might have important theoretical and practical implications. This study has contributed to the existing literature in a number of ways. First, our findings of no significant effect of CSR disclosures on accounting returns did not support the stakeholder theory. Stakeholder theory is the perspective that business activities aimed at satisfying the stakeholders should help the business to create competitive advantage and improve the financial performance (Freeman \& Evan, 1990). The results of the study align with Friedman's (1970) claim that business firms should not engage in social responsibility. Second, the research examines empirically the relation between CSR activities and financial performance in companies that perceive CSR activities as a tool for gaining and retaining legitimacy. Third, the research fills the gap in existing literature on CSR by adding Polish perspective on the phenomena, thereby enhancing our current understanding of the impact of CSR activities on FP in banking industry. Fourth, this study was conducted in Poland that is perceived as a very important emerging economy in Central and Eastern Europe. Thus, the findings regarding to relation between CSR and FP in Polish banks could have serious implications in other emerging economies in particular in Central and Eastern Europe region.

The findings of this study revealed also several practical implications and recommendations. First, the results of the study imply that, in order to be rewarded with legitimacy by stakeholders, managers should spend more resources and effort on their CSR activities and in longer perspective they might expect positive impact on financial performance. This therefore calls for increased shareholders' understanding of the managerial actions. The owners of shares would be better informed of actions taken by the management, if they were involved in organization's activity (OECD 2008). Therefore, the following recommendation for the management can be specified: (1) managers should ensure transparency of the managerial process, (2) the full disclosure of relevant information to all stakeholders is needed.

Second, according to Griffin and Prakash (2014), business sector (including banking sector) and government are obliged to effectively participate in CSR, if social 
conduct is to be sustainable. Governments and policy makers needs to encourage the companies to support the provision of public goods. Therefore, there is a need to call on the government to provide fiscal incentives and other stimulating factors to the business sector to encourage them to improve their CSR activities.

\subsection{Limitations and future research}

As with any empirical work, this study suffers from a number of limitations that may further constrain its generalizability and trustworthiness. First, this study is focused on the banking sector in Poland. Hence, the findings are biased and only applicable to that sector. Any attempt to generalize the results of the study beyond its context may render such generalized conclusions invalid.

Second, the sample size of 18 banks, arising from the small population of banks in the country and used for this study was another limitation. The limited number of banks included in the analysis could reduce the validity of the findings and conclusions. Nevertheless, a few empirical studies have used small sample sizes especially in emerging markets.

Third, the CSR disclosure data used for this study constitutes another limitation. The CSR disclosure data were hand collected from management commentaries and corporate social responsibility reports according to self-constructed disclosure checklist. It has the disadvantages to be difficult to replicate because the researcher may generally use his judgement during the coding process which can also bias the overall results.

Fourth, another major limitation to this study relates to the operationalization of both dependent and independent variables. We operationalized financial performance as ROA, ROE and NIM ratios so we use accounting-based approach. Alternative operationalization of the financial performance that exists in the empirical literature uses market-based ratios. To measure CSR disclosures, we used content analysis and we have developed aggregated CSR index, while researchers have measured the CSR in diverse ways including the use of questionnaire surveys, spending measures or third parties' ratings. Using any or a combination of these alternatives could produce different results. In the control variables, operationalization issues also arise. Therefore, differences in the operationalization of the variables may not permit a free generalization of the study or a perfect comparison with other studies.

Fifth, the limited number of control variables we used in this study is also a source of limitations of the study. If more control variables, which appear in the literature, had been included in the study models, we might have obtained different and, possibly, more accurate results. 
Finally, the adopted quantitative design of the study has its inherent limitations and might limit the extent to which the findings may be generalized or replicated. Drawing conclusions merely from the analysis of numerical data to explain social interaction is risky. It is necessary to take into account also human nature, psychology and irrational behaviour of stakeholders.

In this regard, further research is recommended to expand the scope of the study so that It could be possible to determine, how did the relation CSR-FP change over time, especially before and after financial crisis. Such study can compare the impact of CSR disclosures on banks' financial performance in the pre-crisis and post-crisis periods. Apart from the above proposal, other future researches might extend the study by performing in-depth qualitative research to explore the exact meanings the stakeholders attach to the bank CSR activities and disclosures based on them.

Another future research could address the empirical linkage between CSR disclosures and financial performance in the banking sector of other emerging countries. Researchers may want to replicate the study, using content analysis and aggregated CSR index to measure the CSR as was done in this study or using some other forms of methodology to measure both dependent and independent variables. Lastly, some elements of the methodology could be adapted in further research, which examine the influence of CSR disclosure on financial performance in many other sectors. Such comparative studies could be done within the oil and gas, food and manufacturing or production sectors in order to obtain more understanding about the differences amongst them.

\section{Acknowledgements}

We wish to thank Prof. Luc Paugam, Prof. Nadia Albu, and anonymous referee and participants of the AMIS 2017 Conference at the Bucharest University of Economic Studies for their helpful comments. 


\section{References}

Adebayo, E. (2000) "Corporate Social Responsibility Disclosure, Corporate Financial and Social Performance: An Empirical Analysis", Nova Southeastern University: Fort Lauderdale, FL.

Adeyanju, O.D. (2012) "An assessment of the impact of corporate social responsibility on Nigerian society: The examples of banking and communication industries", Universal Journal of Marketing and Business Research, vol. 1(1): 17-43.

Albu, C.N., Balsari, C. \& Krasodomska, J. (2016) "Introduction to the Special issue on Corporate Social Reporting in Central and Eastern Europe", Accounting and Management Information Systems, vol. 15, no. 2: 193-205

Ambec, S. and Lanoie, P. (2008) "Does it pay to be green? A systematic overview", Academy of Management Perspectives, vol. 22(4): 45-62

Arli, D. \& Lasmono, K. H. (2009) "Consumers' perception of corporate social responsibility in a developing country", International Journal of Consumer Studies, vol. 34: 46-51

Baird, P., L., Geylani, P.C. \& Roberts, J.A. (2012) "Corporate social and financial performance re-examined: Industry effects in linear mixed model analysis“, Journal of Business Ethics, vol. 109: 367-388

Bassen, A., Meyer, K. \& Schlange, J. (2006) "The Influence of Corporate Responsibility on the Cost of Capital", SSRN Electronic Journal available online at https://ssrn.com/abstract=984406 (10.05.2017)

Becchetti, L., Ciciretti, R., Hassan, I. \& Kobeissi, N. (2012) "Corporate social responsibility and share value", Journal of Business Research, vol. 65: 16281635

Branco, M.C. \& Rodrigues, L.L. (2006) "Communication of corporate social responsibility by Portuguese banks: A legitimacy theory perspective“, Corporate Communications: An International Journal, vol. 11 (3): 1356-3289

Busch, T. \& Hoffmann, V.H. (2011) "How hot is your bottom line? Linking carbon and financial performance", Business and Society, vol. 50(2): 233-265

Cajias, M., Fuerst, F., \& Bienert, S. (2014) "Can investing in corporate social responsibility lower a company's cost of capital?", Studies in Economics and Finance, vol. 31(2): 202-222

Chen, H. \& Wang, X. (2011) "Corporate social responsibility and corporate financial performance in China: An empirical research from Chinese firms", Corporate Governance, vol. 11 (4): 361-370

Chih, H.L., Chih, H. \& Chen, T. (2010) "On the determinants of corporate social responsibility: International evidence on the financial industry", Journal of Business Ethics, vol. 93: 115-135

Cho, H. \& Patten, D. (2007) "The role of environmental disclosures as tools of legitimacy: A research note", Accounting, Organizations and Society, vol. 32: 639-647 
Cornett, M.M., Erhemjamts, O. \& Tehranian, H. (2016) "Greed or good deeds: An examination of the relation between corporate social responsibility and the financial performance of U.S. commercial banks around the financial crisis", Journal of Banking and Finance, vol. 70: 137-159

Deegan, C.M. (2002) "Introduction. The legitimising effect of social and environmental disclosures - a theoretical foundation", Accounting, Auditing \& Accountability Journal, vol. 15 (3): 282-311

Deegan, D. \& Blomquist, C. (2006) "Stakeholder influence on corporate reporting: an exploration of the interaction between WWF-Australia and the Australian minerals industry", Accounting, Organizations and Society, vol. 31: 343-372

Dhaliwal, D.S., Li, O.Z., Tsang, A. \& Yang, Y.G. (2011) "Voluntary nonfinancial disclosure and the cost of equity capital: The initiation of corporate social responsibility reporting", The Accounting Review, vol. 86(1): 59-100

Dixon-Fowler, H.R., Slater, D.J., Johnson, J.L., Ellstrand, A.E. \& Romi, A.M. (2013) "Beyond "does it pay to be green?" A meta-analysis of moderators of the CEP-CFP relationship", Journal of Business Ethics, vol. 112: 353-366

Dumitrescu, D. \& Simionescu, L. (2015) "Empirical research regarding the influence of corporate social responsibility (CSR) activities on companies' employees and financial performance", Economic Computation \& Economic Cybernetics Studies \& Research, vol. 49(3): 52-66

Freedman, M. \& Patten, D. (2004) "Evidence on the pernicious effect of financial report environmental disclosure", Accounting Forum, vol. 28: 27-41

Freeman, R. \& Evan, W. (1990) "Corporate governance: A stakeholder interpretation", Journal of Behavioral Economics, vol. 19(4): 337

Freeman, R.E. (1984) Strategic management: A stakeholder approach, Boston, MA: Pitman.

Gray, R., Kouhy, R. \& Lavers, S. (1995a) "Corporate social and environmental reporting: A review of the literature and a longitudinal study of UK disclosure", Accounting, Auditing \& Accountability Journal, vol. 8(2): 47-77

Gray, R., Kouhy, R. \& Lavers, S. (1995b) "Methodological themes: Constructing a research database of social and environmental reporting by UK companies", Accounting, Auditing \& Accountability Journal, 8 (2): 78-101

Griffin, J.J. \& Prakash, A. (2014) "Corporate social responsibility: Initiatives and mechanism" Business \& Society, vol. 53(4): 465-482

Haniffa, R.M. \& Cooke, T.E. (2005) "The impact of culture and governance on corporate social reporting", Journal of Accounting and Public Policy, vol. 24: 391-430

Husted, B.W. (2005) "Risk management, real options, and corporate social responsibility", Journal of Business Ethics, vol. 60: 175-183

Jiao, Y. (2010) "Stakeholder welfare and firm value", Journal of Banking and Finance, vol. 34: 2549-2561

Kaplan, S.E. \& Ruland, R.G. (1991) "Positive theory, rationality and accounting regulation", Critical Perspectives on Accounting, vol. 2(4): 361-374 
Khlif, H., Guidara, A. \& Souissi, M. (2015) "Corporate social and environmental disclosure and corporate performance", Journal of Accounting in Emerging Economies, vol. 5: 51-69

Kiliç, M., Kuzey, C. \& Uyar, A. (2015) "The impact of ownership and board structure on Corporate Social Responsibility (CSR) reporting in the Turkish banking industry", Corporate Governance, vol. 15: 357- 374

Kohers, T. \& Simpson, W.G. (2002) "The link between corporate social and financial performance: Evidence from the banking industry", Journal of Business Ethics, vol. 35: 97-109

Kopczewska, K., Kopczewski, T. \& Wócik, P. (2009) "Metody ilościowe w R. Aplikacje ekonomiczne i finansowe" [Quantitative methods in R. Economic and financial applications] CeDeWu, Warszawa.

Krasodomska, J. (2012) "Znaczenie społecznej odpowiedzialności banków dla bezpieczeństwa systemu finansowego" [Importance of social responsibility of banks for the safety of the financial system], Zeszyty Naukowe, Polskie Towarzystwo Ekonomiczne, no. 12: 151-159

Matthews, M.R. (1993) Socially responsible accounting, London: Chapman \& Hall.

Molyneux ,P., Schaeck, K. \& Zhou, T. (2014) "Too systemically important to fail' in banking - Evidence from bank mergers and acquisitions"”, Journal of International Money and Finance, vol. 49: 258-282

Nollet, J., Filis, G. \& Mitrokostas, E. (2015) "Corporate social responsibility and financial performance: A non-linear and disaggregated approach", Economic Modelling, vol. 52: 400-407

Organization for Economic Co-operation and Development (2008) OECD principles of corporate governance, available on-line at http://www.oecd.org/dataoecd/32/18/31557724.pdf (2016-12-01)

Orlitzky, M., Schmidt, F.L. \& Rynes, S.L. (2003) "Corporate social and financial performance: A meta-analysis", Organization Studies, vol. 24(3): 403-441

Patten, D. (1991) "Exposure, legitimacy, and social disclosure", Journal of Accounting and Public Policy, vol. 10: 297-308

Patten, D. (1992) "Intra-industry environmental disclosures in response to the Alaskan oil spill: A note on legitimacy theory", Accounting, Organizations and Society, vol. 17(5): 471-475

Patten, D. (2000) "Changing superfund disclosure and its relations to other environmental disclosure", Advances in Environmental Accounting and Management, vol. 1: 101-122

Servaes, H. \& Tamayo, A. (2013) "The impact of corporate social responsibility on firm value: the role of customer awareness", Management Science, vol. 59: 1045-1061.

Sharma, S. \& Starik, M. (Eds.) (2002) Research in corporate sustainability: The evolving theory and practice of organizations in the natural environment, Northampton: Edward Elgar Academic Publishing. 
Shen, C.H., Wu, M.W., Chen, T.H. \& Fange, H. (2016) “To engage or not to engage in corporate social responsibility: Empirical evidence from global banking sector”, Economic Modelling, vol. 55: 207-225

Siregar, S.V. \& Bachtiar, Y. (2010) "Corporate social reporting: Empirical evidence from Indonesia Stock Exchange“, International Journal of Islamic and Middle Eastern Finance and Management, vol. 3 (3): 241-252

Soana, M. (2011) "The relationship between corporate social performance and corporate financial performance in the banking sector", Journal of Business Ethics, vol. 104: 133-148

Suchman, M.C. (1995) "Managing legitimacy: strategic and institutional approaches", Academy of Management Review, vol. 20 (3): 571-610

Szpringer, S. (2009) "Społeczna odpowiedzialność banków. Między ochroną konsumenta a osłoną socjalną" [Social responsibility of banks. Between consumer protection and social protection], Oficyna a Wolters Kluwer business, Warszawa.

Tafti, S.F., Hosseini, S.F. \& Emami, S.A. (2012) "Assessment of the corporate social responsibility according to Islamic values (Case study: Sarmayeh Bank)", Procedia - Social and Behavioral Sciences, vol. 58: 1139-1148

Taskin, D. (2015) "The Relationship between CSR and Banks' Financial Performance: Evidence from Turkey", Journal of Yaşar University, vol. 10(39): 21-30

Torres, A., Bijmolt, T.H.A., Tribo, J.A. \& Verhoef, P. (2012) "Generating global brand equity through corporate social responsibility to key stakeholders", International Journal of Research in Marketing, vol. 29: 13-24

Waniak-Michalak, H., Macuda, M. \& Krasodomska, J. (2016) "Corporate Social Responsibility and accounting in Poland: a literature review", Accounting and Management Information Systems, vol. 15(2): 242-303

Weshah, S., R., Dahiyat, A.A., Awwad, M., R.A. \& Hajjat, E.S. (2012) “The impact of adopting corporate social responsibility on corporate financial performance: Evidence from Jordanian banks", Interdisciplinary Journal of Contemporary Research in Business, vol. 4(5): 34-44

Wu, M.W. \& Shen, C.H. (2013) "Corporate social responsibility in the banking industry: Motives and financial performance", Journal of Banking and Finance, vol. 37 (9): 3529-3547 
Appendix A

CSR disclosure items

\begin{tabular}{|c|c|c|}
\hline \multicolumn{2}{|c|}{ Environment } & References \\
\hline EN1 & Statement on environmental protection policy & \multirow{10}{*}{$\begin{array}{l}\text { GRI Standards } 2016 \\
\text { (GRI 301: Materials, } \\
\text { GRI 302: Energy, } \\
\text { GRI 303: Water, } \\
\text { GRI 304: } \\
\text { Biodiversity, GRI } \\
\text { 306: Effluents and } \\
\text { Waste); } \\
\text { Kiliç et al. } 2015 .\end{array}$} \\
\hline EN2 & $\begin{array}{l}\text { Prevention of pollution (waste disposal and } \\
\text { recycling) }\end{array}$ & \\
\hline EN3 & $\begin{array}{l}\text { Actions aiming to limit consumption of energy, } \\
\text { materials, water (sustainable use of resources) }\end{array}$ & \\
\hline EN4 & $\begin{array}{l}\text { Sustainability (any mention of sustainable } \\
\text { development) }\end{array}$ & \\
\hline EN5 & $\begin{array}{l}\text { Aesthetic value of the environment (designing } \\
\text { structures in harmony with the environment, } \\
\text { landscape) }\end{array}$ & \\
\hline EN6 & $\begin{array}{l}\text { Environmental protection, biodiversity and } \\
\text { restoration of natural habitats }\end{array}$ & \\
\hline EN7 & $\begin{array}{l}\text { Taking account of the environment in credit policy } \\
\text { (environmentally-friendly products, "green } \\
\text { products", funding "low-emission" investment } \\
\text { projects ...) }\end{array}$ & \\
\hline EN8 & $\begin{array}{l}\text { Environmental training and certificates (ISO } 14001 \\
\text { vs) }\end{array}$ & \\
\hline EN9 & $\begin{array}{l}\begin{array}{l}\text { Joint projects with other companies providing } \\
\text { environmental management services }\end{array} \\
\end{array}$ & \\
\hline EN10 & Environmental awards & \\
\hline \multicolumn{2}{|c|}{ Human Resources } & References \\
\hline HR1 & Employment and labour & \multirow{6}{*}{$\begin{array}{l}\text { GRI Standards } 2016 \\
\text { (GRI 401: } \\
\text { Employment, GRI } \\
\text { 402: Labor/ } \\
\text { Management } \\
\text { Relations, GRI 403: } \\
\text { Occupational Health } \\
\text { and Safety, GRI 404: }\end{array}$} \\
\hline HR2 & Occup & \\
\hline HR3 & Employee development (training...) & \\
\hline HR4 & $\begin{array}{l}\text { Employee benefits (insurance, healthcare, social } \\
\text { assistance ...) }\end{array}$ & \\
\hline HR5 & ships with trade unions & \\
\hline HR6 & nployee turnover & \\
\hline HR7 & $\begin{array}{l}\text { Information on support for daytime care, maternity } \\
\text { and paternity leave }\end{array}$ & $\begin{array}{l}\text { Training and } \\
\text { Education, GRI 405: }\end{array}$ \\
\hline HR8 & $\begin{array}{l}\text { Encouraging diversity (employment of minorities, } \\
\text { disabled persons, women ...) }\end{array}$ & $\begin{array}{l}\text { Diversity and Equal } \\
\text { Opportunity); } \\
\text { Kiliç et al. 2015. }\end{array}$ \\
\hline \multicolumn{2}{|r|}{ Product and customers } & References \\
\hline PC1 & $\begin{array}{l}\text { Comprehensibility and } \mathrm{tr} \\
\text { services }\end{array}$ & $\begin{array}{l}\text { GRI Standards } 2016 \\
\text { (GRI 416: Customer }\end{array}$ \\
\hline
\end{tabular}


An examination of the relationship between CSR disclosure and financial performance: The case of Polish banks

\begin{tabular}{|c|c|c|}
\hline PC2 & $\begin{array}{l}\text { Bank products addressed to marginalised groups } \\
\text { (the disabled, aged customers, non-profit } \\
\text { organisations ...) }\end{array}$ & \multirow{5}{*}{$\begin{array}{l}\text { Health and Safety, } \\
\text { GRI 417: Marketing } \\
\text { and Labelling, GRI } \\
\text { 418: Customer } \\
\text { Privacy); } \\
\text { Kiliç et al. } 2015 . \\
\end{array}$} \\
\hline PC3 & $\begin{array}{l}\text { Examination of customer satisfaction / service } \\
\text { quality }\end{array}$ & \\
\hline PC4 & Protection of customers' data and privacy & \\
\hline PC5 & $\begin{array}{l}\text { Customer service (settlement of problems, } \\
\text { complaints, disputes, renegotiation of contract } \\
\text { terms ...) }\end{array}$ & \\
\hline PC6 & Consumer awards & \\
\hline \multicolumn{2}{|r|}{ Community Involvement } & References \\
\hline CI1 & $\begin{array}{l}\text { Donations for social activities and public benefit } \\
\text { organisations }\end{array}$ & \multirow{5}{*}{$\begin{array}{l}\text { GRI Standards } 2016 \\
\text { (GRI 413: Local } \\
\text { Communities); } \\
\text { Kiliç et al. 2015. }\end{array}$} \\
\hline CI2 & $\begin{array}{l}\text { Support for education (scholarships, conferences, } \\
\text { seminars, student internships...) }\end{array}$ & \\
\hline CI3 & $\begin{array}{l}\text { Sponsorship of various sport, artistic and cultural } \\
\text { events }\end{array}$ & \\
\hline CI4 & $\begin{array}{l}\text { Sponsorship of various public health initiatives, } \\
\text { projects, campaigns }\end{array}$ & \\
\hline CI5 & Support for local activities, industry, agriculture & \\
\hline
\end{tabular}

\footnotetext{
${ }^{i}$ Notoria Serwis Database contains an updated, standardized format of financial statements for all companies listed on the Warsaw Stock Exchange - reporting both in accordance with Polish and international accounting standards.
} 